\title{
Novel Advanced Treatment of Physically Treated Effluent from Herbal Decoction Pieces Wastewater Using a Combined Ozone/Persulfate-UBAF Process
}

\author{
Guomin Tang ${ }^{1-4 *}$, Weiyu Chen ${ }^{1}$, Yujiang Wei, Ting Shao ${ }^{1}$, Mengyuan Zhang1, \\ Zhehua $\mathrm{Jia}^{2}$, Xuemin $\mathrm{Yu}^{4}$, Fang $\mathrm{Ma}^{3}$ \\ ${ }^{1}$ Taizhou Institute of Science and Technology, Nanjing University of Science and Technology, \\ Taizhou, Jiangsu Province, China \\ ${ }^{2}$ Province Key Laboratory of Environmental Material and Environmental Engineering, \\ Yangzhou University, Yangzhou, Jiangsu Province, China \\ ${ }^{3}$ State Key Laboratory of Urban Water Resource and Environment, Harbin Institute of Technology, \\ Harbin, Heilongjiang Province, China \\ ${ }^{4}$ Province Key Laboratory of Environmental Engineering, Jiangsu Environmental Science Research Institute, \\ Nanjing, Jiangsu Province, China
}

Received: 26 March 2018

Accepted: 10 June 2018

\begin{abstract}
Performance of ozone/persulfate-UBAF used for advanced treatment of physically treated effluent from herbal decoction pieces of wastewater was investigated in a pilot scale experiment. Under optimum conditions - i.e., an initial $\mathrm{pH}$, temperature $13-27^{\circ} \mathrm{C}, 30 \mathrm{~min}$ of oxidation, $35 \mathrm{mg} / \mathrm{L} \mathrm{O}$ dosage, $\mathrm{S}_{2} \mathrm{O}_{8}{ }^{2-} / \mathrm{COD}(\mathrm{g} / \mathrm{g})$ ratio (0.15), gas/liquid ratio in UBAF (3), hydraulic retention time in UBAF (5h) - the COD and $\mathrm{NH}_{3}-\mathrm{N}$ removal efficiencies were $87.54-89.53 \%$ and $82.94-86.77 \%$, respectively. Under optimum conditions, ozone/persulfate oxidation lowered $\mathrm{pH}$ values by about $0.1 \mathrm{pH}$ units (average value), presented lower OCC (from 0.14 to $0.16 \mathrm{~kg} \mathrm{O}_{3} / \mathrm{kg}$ COD removed), and significantly improved the wastewater biodegradability from 0.16 to 0.55 (average value). Compared with $\mathrm{O}_{3} / \mathrm{H}_{2} \mathrm{O}_{2}$ oxidation, the ozone/persulfate system achieved a better enhancement effect in wastewater treatment (i.e., decreased $24.0 \%$ OCC and saved $11.4 \%$ in operational costs). Furthermore, the COD removal rate in ozone/persulfate oxidation stage followed the first order $\ln \left(\frac{C}{C_{0}}\right)=-0.0167 t$, and the COD concentration in UBAF effluent was expressed by the model $\frac{C}{C_{0}}=\exp \left(-\frac{0.2940}{L^{0.0912}} H\right)$ at various hydraulic loading rates
\end{abstract}

*e-mail: tgm333@njust.edu.cn 
for maintenance and selection of UBAF. Finally, the study proved that the combined process was an efficient technology in treating physically treated effluent from herbal decoction pieces wastewater.

Keywords: physically treated effluent; herbal decoction pieces wastewater; ozone/persulfate oxidation; biodegradability; ozone consumption coefficient

\section{Introduction}

Herbal decoction pieces wastewater, a typical refractory biodegradable industry wastewater, contains plenty of refractory organic pollutants (e.g., cellulose, lignin). Recently, biological-physically treated effluent from herbal decoction pieces wastewater was often discharged into natural water environments beyond standard without appropriate treatment [1, 2]. Meanwhile, with the implementation of more stringent discharge standards, the efficient and reliable operation of a wastewater treatment system had also become a severe problem in herbal decoction pieces factories. Therefore, aiming at the strictest discharge standards, it was imperative for herbal decoction pieces factories to seek an advanced treatment technology possessing a series of advantages (e.g., good operational stability, high-quality effluent). Unfortunately, until now, relevant research has not been reported publicly.

Compared with other advanced treatment technologies, the coupling process of advanced oxidation-advanced aerobic treatment has recently caused more and more attention [3-5]. upflow biological aerated filter (UBAF), as a typical representative of advanced aerobic treatment, presented an excellent performance in advanced treatment of industry wastewater containing low concentrations of SS and COD. Among the numerous oxidation reagents, the usual oxidant mainly included Fenton reagent and ozone in engineering practice. However, in the use of these oxidants, there were some troublesome problems such as voluminous sludge production, low removal efficiency, and worse ability of wastewater biodegradability enhancement. Compared with the above oxidant, persulfate $\left(E^{0}=2.01 \mathrm{~V}\right)$, as the newest advanced oxidant, has recently raised more and more attention. What's more, sulfite-free radical initiated from persulfate possess a strong oxidation ability $\left(E^{0}=2.7 \mathrm{~V}\right)$ [6-13]. The previous study reported that hydroxyl-free radicals could be generated under the $\mathrm{O}_{3}$ effect $[14,15]$. Compared with the hydroxyl-free radical, sulfate-free radical was more effective in degradating some organic compounds in wastewater because it was more selective to oxidation. However, up till now, a rare study has been published regarding ozone/persulfate as the advanced oxidation process used to treat real industry wastewater. Thus, a new combined process (ozone/persulfate-UBAF) was designed in the advanced treatment of physically treated effluents from herbal decoction pieces wastewater.

The main objectives of the study included: (1) determining optimum operational conditions; (2) examining the treatment performance on the combined process and ozone/persulfate oxidation under optimum operational conditions; (3) identifying COD removal behaviors in ozone/persulfate oxidation and UBAF; (4) evaluating the effect of ozone/persulfate oxidation on ozone consumption coefficient, wastewater biodegradability, and wastewater $\mathrm{pH}$; and (5) comparing between $\mathrm{O}_{3} / \mathrm{H}_{2} \mathrm{O}_{2}$ and $\mathrm{O}_{3} / \mathrm{S}_{2} \mathrm{O}_{8}{ }^{2-}$.

\section{Experimental}

\section{Experimental Influent}

The physically treated effluent in the sampled factory flowed into the influent tank in the experiment. The influent quality was shown in Table 1.

\section{Experimental Setup}

\section{Setup I}

The optimization experiment on ozone/persulfate oxidation time and the COD removal behavior experiment on ozone/persulfate oxidation were carried out with a $500 \mathrm{~mL}$-capacity glass in setup I (Fig. 1a).

To rapidly terminate oxidation reaction, the $0.2 \mathrm{~mL}$ $\mathrm{Na}_{2} \mathrm{SO}_{3}$ solution $(85.0 \mathrm{mM})$ was immediately added into the wastewater sample $(10 \mathrm{~mL})$ and withdrawn at regular time interval. Subsequently, the sample was used to the following indicator analysis.

Table 1. Experiment influent quality.

\begin{tabular}{|c|c|c|c|c|c|}
\hline Indicator & $\mathrm{COD}(\mathrm{mg} / \mathrm{L})$ & $\mathrm{NH}_{3}-\mathrm{N}(\mathrm{mg} / \mathrm{L})$ & $\mathrm{BOD}_{5}(\mathrm{mg} / \mathrm{L})$ & $\mathrm{pH}$ & $\mathrm{SS}(\mathrm{mg} / \mathrm{L})$ \\
\hline Value & $350-360$ & $28-35$ & $52-62$ & $7.2-8.9$ & $80-95$ \\
\hline
\end{tabular}

Note: The key indicators assigned by the local environmental protection bureau included COD and $\mathrm{NH}_{3}-\mathrm{N}_{\text {. }}$ 

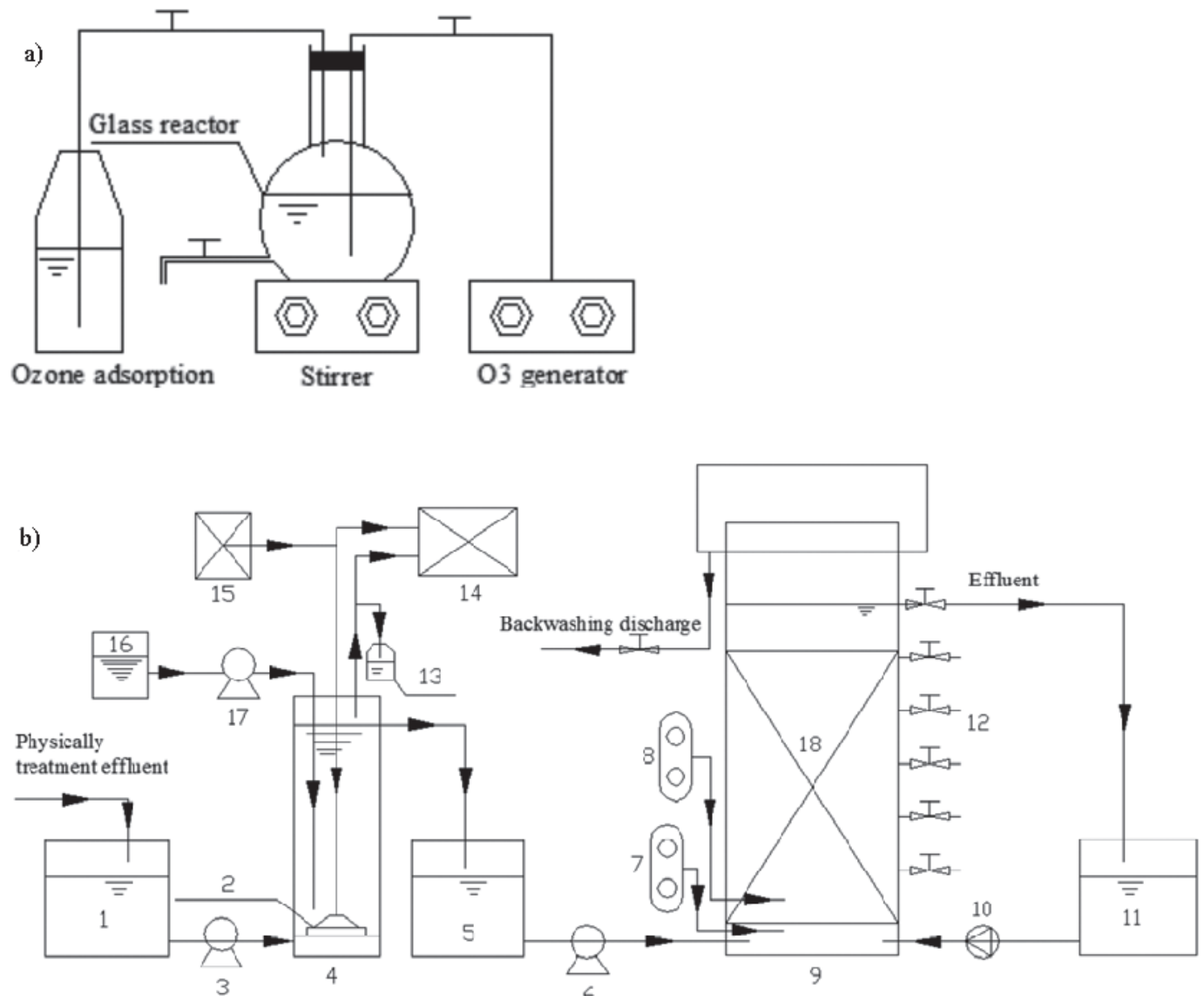

Fig. 1. Experiment setup: a) setup I, b) setup II. (1) influent tank $(1100 \times 1100 \times 1000 \mathrm{~mm})$; (2) microspore aerator $(\Phi 100 \mathrm{~mm})$; (3) influent pump (JGX-170/0.3); (4) oxidation reactor $(\Phi 200 \times 2000 \mathrm{~mm})$; (5) intermediate water tank $(350 \times 350 \times 400 \mathrm{~mm})$; $(6)$ influent pump (JGX-170/0.3); (7) backwashing air blower (ACO500); (8) aeration blower (MPQ-904); (9) BAF (Ф600 × $3000 \mathrm{~mm})$; (10) backwashing pump (DBZ-45); (11) effluent tank $(1100 \times 1100 \times 1000 \mathrm{~mm})$; (12) sampling port; (13) excessive ozone absorbed system; (14) ozone monitor (HD80-O3); (15) ozone generator (CF-G-2); (16) persulfte solution tank; (17) wringgle pump; (18) ceramic particle.

\section{Setup II}

The other experiments were carried out in setup II (an ozone/persulfate-UBAF reactor) (Fig. 1b).

In the experiment, $\mathrm{S}_{2} \mathrm{O}_{8}{ }^{2-}$ as sodium persulfate $\left(\mathrm{Na}_{2} \mathrm{~S}_{2} \mathrm{O}_{8}\right.$, industrial grade) was provided by Wuhan Galaxy Chemical Co. Ltd and diluted into liquor with $15 \%$ mass concentrations to facilitate dosing. The $\mathrm{O}_{3}$ was produced by a CF-G-2 generator (Guolin and Baifeng, China) fed with pure oxygen (industry grade), following a gas flow rate of $10 \mathrm{~L} / \mathrm{min}$, and pressure of 1 atm. The ozone concentration in input gas was adjusted by working electricity.

The UBAF was packed with ceramic particles (diameter (3-5 mm), packed density $\left.\left(0.95 \mathrm{~g} / \mathrm{cm}^{3}\right)\right)$, HRT at UBAF was $5 \mathrm{~h}$, gas/water ratio at UBAF was 3 , and backwash period was one week. All experiments were carried out at $13-27^{\circ} \mathrm{C}$.

\section{Analytical Methods}

Standard methods of P.R. China were used for determining $\mathrm{COD}, \mathrm{pH}, \mathrm{NH}_{3}-\mathrm{N}, \mathrm{BOD}_{5}$, and $\mathrm{SS}$ in wastewater [16]. Among these indicators, $\mathrm{COD}$ and $\mathrm{pH}$ were determined respectively by dichromate method and glass electrode method, salicylic acid spectrophotometry and gravimetric method were used for determining $\mathrm{NH}_{3}-\mathrm{N}$ and SS, respectively, and $\mathrm{BOD}_{5}$ was measured with dilution and seeding method. Finally, an ozone analyzer (Model $\mathrm{HD} 80-\mathrm{O}_{3}$ ) was used to determine the concentration of the ozone in gas.

\section{COD Removal Behavior in BAF}

With the assumption of plug flow and pseudo firstorder kinetics in UBAF, COD removal rate may be described as follows [17]:

$$
\frac{d C}{d t}=-k_{1} X C
$$

...where $C$ was COD concentration value $(\mathrm{mg} / \mathrm{L})$, $\mathrm{d} C / \mathrm{d} t$ was COD removal rate $(\mathrm{mg} / \mathrm{L} \cdot \mathrm{h}), k_{l}$ was a rate constant $(\mathrm{L} / \mathrm{mg} \cdot \mathrm{h})$, and $X$ is the volatile suspended solids concentration (VSS, $\mathrm{mg} / \mathrm{L}$ ).

Generally, $X$ was expressed as follows:

$$
X=f(A)
$$


...where $A$ was specific surface area of the medium $\left(\mathrm{m}^{2} / \mathrm{m}^{3}\right)$. Substituting Eq. (2) into

Eq. (1), leads to Eq. (3):

$$
\frac{d C}{d t}=-k_{1} f(A) C=-K_{1} C
$$

...where $K_{1}$ was the reaction rate constant.

Integrating Eq. (3) yields:

$$
\frac{C}{C_{0}}=\exp \left(-K_{1} t\right)
$$

...where $t$ was hydraulic retention time (HRT), which could be described as:

$$
t=\frac{D H}{L^{n}}
$$

...where $n$ and $D$ were constants related to specific surface and the medium and, respectively, $L$ was the hydraulic loading rate and $H$ was the medium height.

Substitution Eq. (5) into Eq. (4), leads to

$$
\frac{C}{C_{0}}=\exp \left(-\frac{K H}{L^{n}}\right)
$$

...where $K=K_{l} D$.

Integrating Eq. (6) yields:

$$
\ln \frac{C_{0}}{C}=\frac{K}{L^{n}} H
$$
By plotting $\ln \left(C_{o} / C\right)$ against $H$, the value of $\left(\frac{K}{L^{n}}\right)$
could be determined.

Integrating $\left(\frac{K}{L^{n}}\right)$ yields:

$$
\ln \left(\frac{K}{L^{n}}\right)=\ln K-n \ln L
$$

By plotting $\left(\frac{K}{L^{n}}\right)$ against $\ln L$, the constant $n$ and the constant $K$ could be determined.

\section{Results and Discussion}

The Overall Performance of the Combined Process

The startup of the UBAF seed with activated sludge from the sampled factory took about two months. Then the combined process turned to continuous operation.

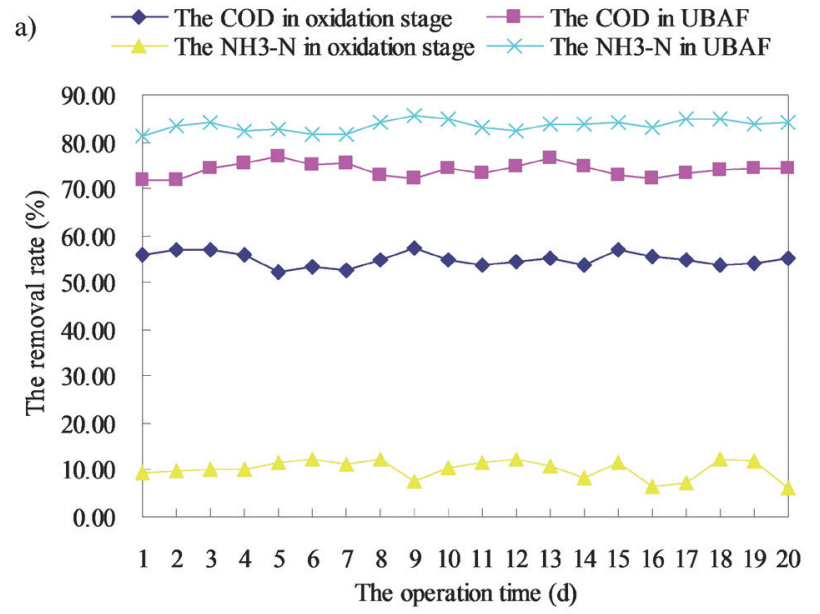

b)

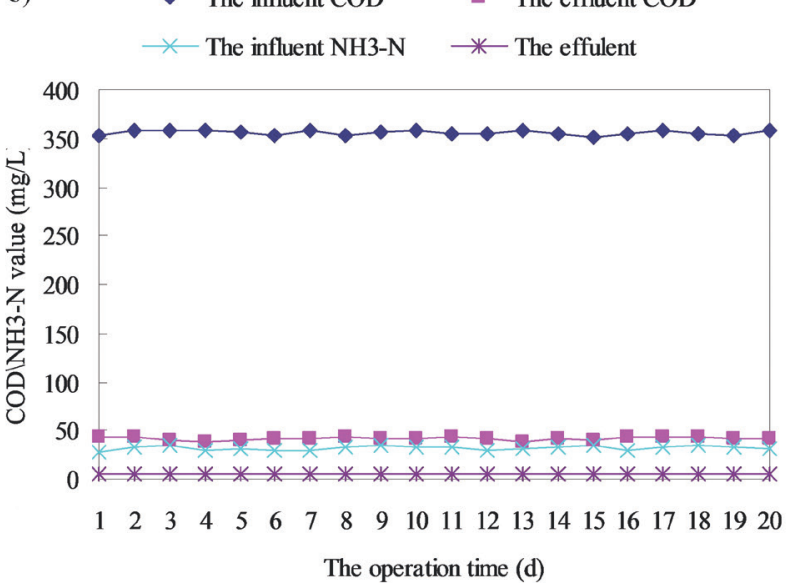

Fig. 2. Operational performance: a) oxidation stage and UBAF, b) the combined process. Under optimum conditions (30 min oxidation, $\mathrm{O}_{3}$ dosage $(35 \mathrm{mg} / \mathrm{L}), \mathrm{S}_{2} \mathrm{O}_{8}{ }^{2-} / \mathrm{COD}(\mathrm{g} / \mathrm{g})$ ratio $(0.15)$, initial $\mathrm{pH}$, a gas to liquid ratio (3), hydraulic retention time of $\operatorname{UBAF}(5 \mathrm{~h})$, temperature $\left(13-27^{\circ} \mathrm{C}\right)$.

A subsequent period of a month was allowed for the steady operation. The overall performance of the combined process was examined (Fig. 2).

The ozone/persulfate oxidation respectively achieved $52.37-57.15 \%$ COD removal and $6.17-12.36 \% \mathrm{NH}_{3}-\mathrm{N}$ removal, the $\mathrm{COD}$ and $\mathrm{NH}_{3}-\mathrm{N}$ in the effluent after ozone/persulfate oxidation were $152.3-170.2 \mathrm{mg} / \mathrm{L}$ and 25.53-31.51 mg/L, respectively (Fig. 2a).

Furthermore, it can be also seen from Fig. 2a) that a $71.83-76.63 \%$ COD removal and $81.16-85.69 \%$ $\mathrm{NH}_{3}-\mathrm{N}$ removal were attributed to the UBAF, the $\mathrm{COD}$ and $\mathrm{NH}_{3}-\mathrm{N}$ in the effluent after the UBAF were $38.56-44.0 \mathrm{mg} / \mathrm{L}$ and $4.51-4.86 \mathrm{mg} / \mathrm{L}$, respectively.

Overall, the removal efficiencies for COD and $\mathrm{NH}_{3}-\mathrm{N}$ were, respectively, $87.54-89.53 \%$ and $82.94-86.77 \%$ in the combined process, and the effluent $\mathrm{COD}$ and $\mathrm{NH}_{3}-\mathrm{N}$ were always below $45 \mathrm{mg} / \mathrm{L}$ and $5.0 \mathrm{mg} / \mathrm{L}$. COD removal depended on ozone/persulfate oxidation and UBAF, and the $\mathrm{NH}_{3}-\mathrm{N}$ removal was mainly attributed to the UBAF (Fig. 2b). 


\section{Evolution of Removal Efficiency as Afunction of Operation Parameter in Oxidation Stage}

\section{Reaction Time}

The effect of reaction time on removal efficiency is shown in Fig. 3a), which showed that removal efficiency was rapidly increased before $30 \mathrm{~min}$, and that COD removal rate was $25.6 \%$ at $30 \mathrm{~min}$, but the rising tendency began to slow after $30 \mathrm{~min}$. This was perhaps because the oxidant (e.g., $\mathrm{O}_{3}$, persulfate, $\mathrm{HO}, \mathrm{SO}_{4}^{-}$) in the wastewater was less and less after $30 \mathrm{~min}$, which resulted in the decrease of rising tendency on removal efficiency. An optimum reaction time $(120 \mathrm{~min})$ was reported during the $\mathrm{S}_{2} \mathrm{O}_{8}{ }^{2-} / \mathrm{H}_{2} \mathrm{O}_{2}$ oxidation of the stabilized landfill leachate [18]. Abu Amr et al. [15] obtained an optimum reaction time $(210 \mathrm{~min})$ during the ozone/persulfate oxidation of the stabilized leachate. $\mathrm{Lu}$ et al. [19] achieved a 95.9\% Rhodamine $\mathrm{B}$ (RhB) degradation within 30 minutes with the $\mathrm{Fe}^{3+} /$ persulfate system. The deviation on the optimal reaction time maybe was mainly due to the variations on the oxidation system (e.g., structure of experimental setup and oxidants such as $\mathrm{H}_{2} \mathrm{O}_{2}$ and $\mathrm{Fe}^{3+}$ ).

\section{$\mathrm{O}_{3}$ Dosage}

Fig. 3b) shows the evolution of removal efficiency as a function of $\mathrm{O}_{3}$ dosage. The removal efficiency was also increased rapidly before $35 \mathrm{mg} / \mathrm{L}$ of $\mathrm{O}_{3}$ dosage, and COD removal efficiency was up to $40.1 \%$ at $35 \mathrm{mg} / \mathrm{L}$ of $\mathrm{O}_{3}$ dosage, and the rising tendency on removal efficiency was not obvious after $35 \mathrm{mg} / \mathrm{L}$ of $\mathrm{O}_{3}$ dosage (Fig. 3b). At a lower $\mathrm{O}_{3}$ dosage, the $\mathrm{O}_{3}$ increase has led to a rapid increase of $\mathrm{HO}$ concentration in wastewater (Eqs. (9-11)) [14]. Accordingly, the $\mathrm{SO}_{4}^{-}$ concentration in the solution would be significantly improved under the HO• effect (Eq. 12) [15]. Meanwhile, $\mathrm{HO} \cdot$ generated under $\mathrm{SO}_{4}^{--}$effect (Eqs. 13-14) [20, 21] would initiate more sulfate-free radicals (Eq. 12). At the moment, the wastewater contained large amount of $\mathrm{HO} \cdot$ and $\mathrm{SO}_{4}^{--}$, which resulted in the formation of the oxidation system possessing stronger oxidation ability.

$$
\begin{gathered}
\mathrm{O}_{3}+\mathrm{OH}^{-} \rightarrow \mathrm{HO}_{2}^{-}+\mathrm{O}_{2} \\
\mathrm{O}_{3}+\mathrm{HO}_{2}^{-} \rightarrow \mathrm{HO}_{2} \cdot+\mathrm{O}_{3}^{-} . \\
\mathrm{O}_{3}^{-} \cdot+\mathrm{H}_{2} \mathrm{O} \rightarrow \mathrm{HO} \cdot+\mathrm{O}_{2}+\mathrm{OH}^{-} \\
\mathrm{S}_{2} \mathrm{O}_{8}^{2-}+\mathrm{HO} \bullet \rightarrow \mathrm{HSO}_{4}^{-}+\mathrm{SO}_{4}^{--}+0.5 \mathrm{O}_{2} \\
\mathrm{SO}_{4}^{--}+\mathrm{H}_{2} \mathrm{O} \rightarrow \mathrm{SO}_{4}^{2-}+\mathrm{HO} \bullet+\mathrm{H}^{+} \\
\mathrm{SO}_{4}^{--}+\mathrm{OH}^{-} \rightarrow \mathrm{SO}_{4}^{2-}+\mathrm{HO} \bullet
\end{gathered}
$$
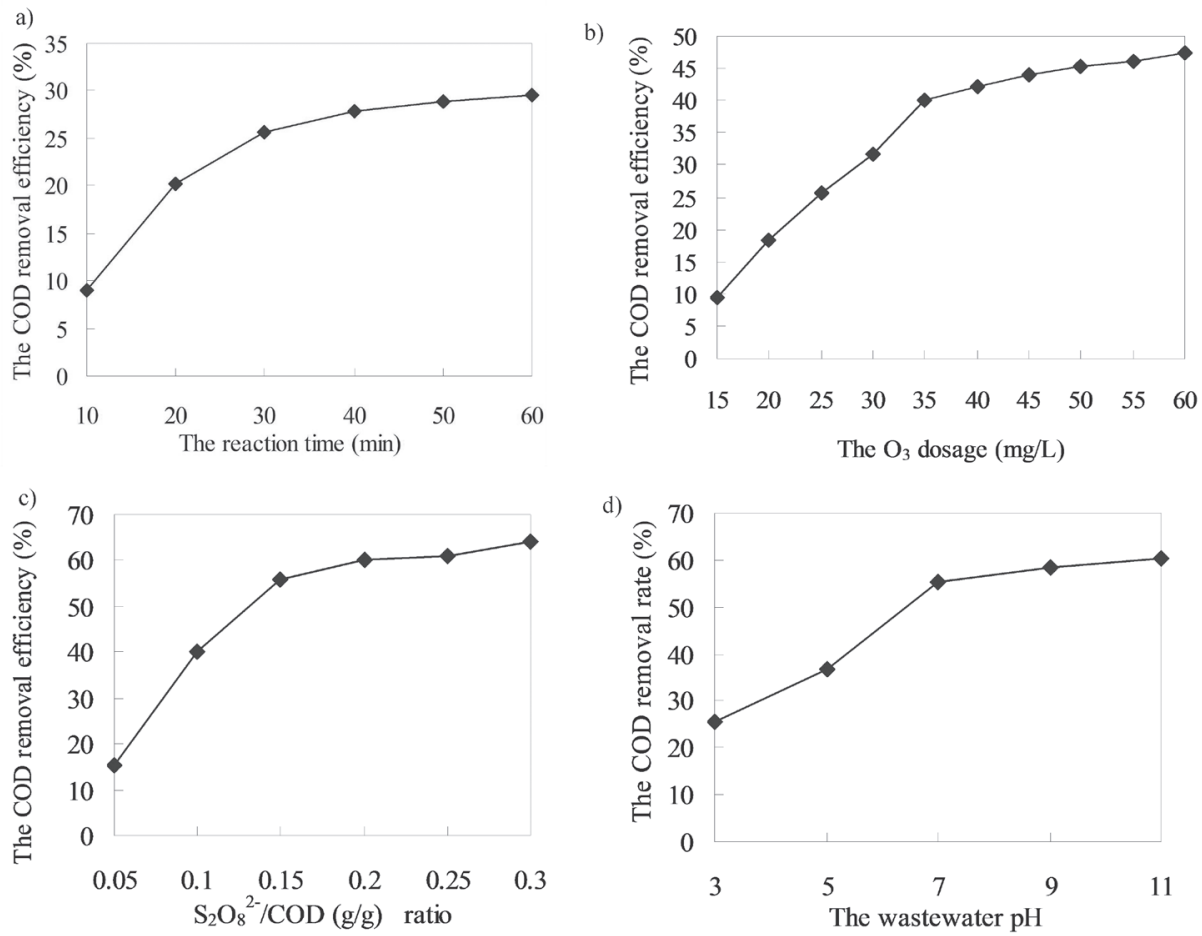

Fig. 3. Evolution of removal efficiency as function of operation parameter: a) reaction time, b) $\mathrm{O}_{3}$ dosage, c) $\mathrm{S}_{2} \mathrm{O}_{8}{ }^{2-} / \mathrm{COD}(\mathrm{g} / \mathrm{g}$ ) ratio, d) wastewater $\mathrm{pH})$ in oxidation stage under operation conditions. a) $\mathrm{O}_{3}$ dosage $(25 \mathrm{mg} / \mathrm{L}), \mathrm{S}_{2} \mathrm{O}_{8}^{2-} / \mathrm{COD}(\mathrm{g} / \mathrm{g})$ ratio $(0.10)$, initial $\mathrm{pH}$, temperature $\left(13-27^{\circ} \mathrm{C}\right)$; b) $30 \mathrm{~min}$ oxidation, $\mathrm{S}_{2} \mathrm{O}_{8}{ }^{2-} / \mathrm{COD}(\mathrm{g} / \mathrm{g})$ ratio $(0.10)$, initial $\mathrm{pH}$, temperature $\left(13-27^{\circ} \mathrm{C}\right)$; c) 30 min oxidation, $35 \mathrm{mg} / \mathrm{L}$ of $\mathrm{O}_{3}$ dosage, initial $\mathrm{pH}$, temperature $\left(13-27^{\circ} \mathrm{C}\right)$ ); d) 30 min oxidation, $35 \mathrm{mg} / \mathrm{L}$ of $\mathrm{O}_{3}$ dosage, $\mathrm{S}_{2} \mathrm{O}_{8}^{2-} / \mathrm{COD}(\mathrm{g} / \mathrm{g})$ ratio $(0.15)$, temperature $\left(13-27^{\circ} \mathrm{C}\right)$. 
But at a high dosage, the excessive $\mathrm{O}_{3}$ would perhaps consume $\mathrm{HO} \cdot$ in the wastewater (Eq. 15) [22], and $\mathrm{SO}_{4}{ }^{-}$-would subsequently decrease under this effect (Eq. 12), which resulted in the decrease of oxidation ability in the ozone/persulfate system.

$$
\mathrm{O}_{3}+\mathrm{HO} \cdot \rightarrow \mathrm{O}_{3}+\mathrm{OH}^{-}
$$

The phenomenon was also observed in other advanced oxidation processes. Abu Amr et al. [15] reported the optimum $\mathrm{O}_{3}$ dosage was $80 \mathrm{~g} / \mathrm{m}^{3}$ during the ozone/persulfate oxidation of the stabilized leachate. Yang et al. [23] observed a $62.43 \%$ BPA removal at a $1.0 \mathrm{mg} / \mathrm{L} \mathrm{O}_{3}$ dosage. Qi et al. [24] obtained an optimal ozone dosage $(20-30 \mathrm{mg} / \mathrm{L})$ while treating textile wastewater with O3-BAF-membrane filtration process.

\section{$\mathrm{S}_{2} \mathrm{O}_{8}^{2-}$ Dosage}

As Fig. 3c) illustrated, the increasing tendency on removal efficiency began to decrease after a $\mathrm{S}_{2} \mathrm{O}_{8}{ }^{2-} / \mathrm{COD}(\mathrm{g} / \mathrm{g})$ ratio of 0.15 . At the $\mathrm{S}_{2} \mathrm{O}_{8}{ }^{2-} / \mathrm{COD}(\mathrm{g} / \mathrm{g})$ ratio of 0.15 , the $\mathrm{COD}$ removal efficiency was up to $55.9 \%$. At a lower $\mathrm{S}_{2} \mathrm{O}_{8}{ }^{2-}$ dosage, enough sulfate-free radicals could not be generated in the wastewater, thus the removal efficiency on COD was limited. With the increase of the $\mathrm{S}_{2} \mathrm{O}_{8}{ }^{2-}$ dosage, more and more sulfatefree radicals and hydroxyl-free radicals would be generated in the wastewater (Eqs. 9-14), which led to the rapid increase of removal efficiency. But at a high $\mathrm{S}_{2} \mathrm{O}_{8}{ }^{2-}$ dosage, perhaps the excessive $\mathrm{S}_{2} \mathrm{O}_{8}{ }^{2-}$ would not generate more $\mathrm{SO}_{4}^{-}$(namely the effective content of sulfate-free radical in wastewater was not improved) because of the exhausting of the $\mathrm{HO} \cdot($ Eq. 12), which resulted in the decrease of rising tendency on removal efficiency. It was reported that the optimum ratio of $\mathrm{S}_{2} \mathrm{O}_{8}{ }^{2-} / \mathrm{COD}(\mathrm{g} / \mathrm{g})$ was 7 during the $\mathrm{O}_{3} / \mathrm{S}_{2} \mathrm{O}_{8}{ }^{2-}$ oxidation of the stabilized leachate [15]. Shabiimam and Anil Kumar [25] obtained an optimum ratio of $\mathrm{S}_{2} \mathrm{O}_{8}{ }^{2-} / \mathrm{COD}(\mathrm{g} / \mathrm{g})(2.14)$ during the $\mathrm{S}_{2} \mathrm{O}_{8}{ }^{2-}$ alone oxidation of the municipal landfill leachate. An optimum ratio of $\mathrm{S}_{2} \mathrm{O}_{8}{ }^{2-} / \mathrm{COD}(\mathrm{g} / \mathrm{g})$ (9.0) was reported during the treatment of reverse osmosis concentrate from the textile and dying industry [26]. The deviation on the optimal ratio of $\mathrm{S}_{2} \mathrm{O}_{8}{ }^{2-} / \mathrm{COD}(\mathrm{g} / \mathrm{g})$ may have resulted from the variations on influent quality and experimental conditions.

At present, it was reported that persulfate could be activated by these methods mentioned in literature (i.e., thermolysis, iron catalysis) [27-29]. Nevertheless, the above results suggest that ozone has good performance on activating persulfate to initiate sulfate-free radical. Compared with ozone oxidation alone and persulfate oxidation alone, the ozone/persulfate oxidation could achieve more excellent performance on pollutant removal.

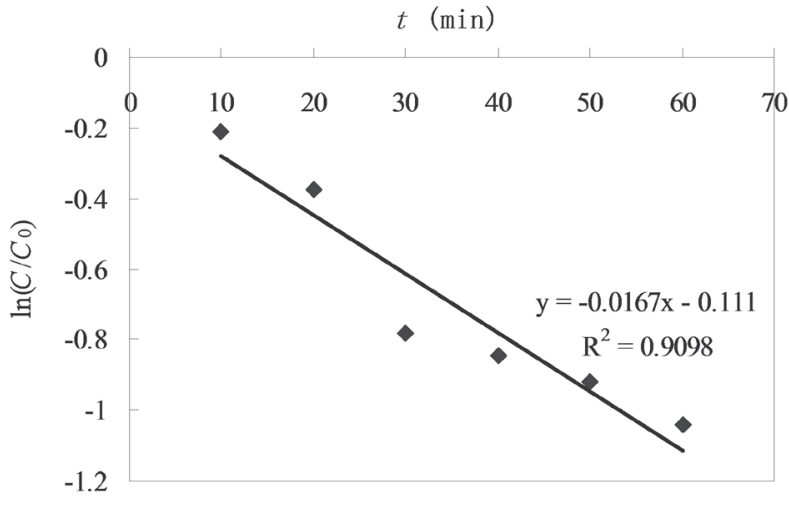

Fig. 4. Relationship between $\ln \left(C / C_{0}\right)$ and $t$.

$$
p H
$$

Fig. 3d) shows that removal efficiency was improved by increasing the $\mathrm{pH}$, and the ozone/persulfate system could also achieve satisfactory removal performance even at initial $\mathrm{pH}$. As $\mathrm{pH}$ further increases, the removal efficiency also increased. This was perhaps because the hydroxide ion was helpful for the generation of the hydroxyl free radical, and consequently more sulfatefree radical was formed under the hydroxyl free radical effect, which resulted in the increase in removal efficiency. Abu Amr et al. [15] reported that the ozone/ persulfate system achieved a preferred removal rate at $\mathrm{pH}=10$. Zheng et al. [26] obtained a satisfactory treatment effect at $\mathrm{pH}$ 5.0. Furthermore, it was also reported that the optimal removal efficiency was achieved at low $\mathrm{pH}(2-4.5)$ [25].

\section{COD Removal Behavior in the Oxidation Stage}

With the assumption of pseudo-first-order kinetics, the following Eq. (16) could be used to describe COD removal rate in the oxidation stage.

$$
\ln \left(\frac{C}{C_{0}}\right)=-K t
$$

...where $t$ was the ozone/persulfate oxidation time, $C$ was COD value at different $t, C_{0}$ were the COD in influent, and $K$ was the rate constant. Under optimum operational conditions, the relationship between $\ln (C /$ $C_{0}$ ) and $t$ is shown in Fig. 4.

The linear fitting of $\ln \left(C / C_{0}\right)$ as a function of $t$ leads to $K=0.0167$, as shown in Fig. 4. Therefore, in the ozone/persulfate oxidation system, the COD removal rate followed the first order (Eq. 17).

$$
\ln \left(\frac{C}{C_{0}}\right)=-0.0167 t
$$




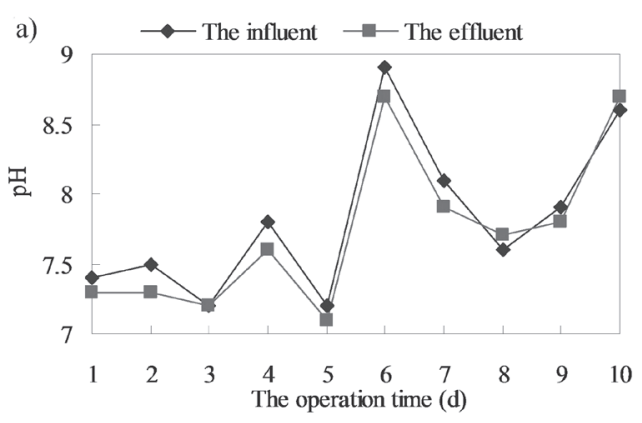

b)
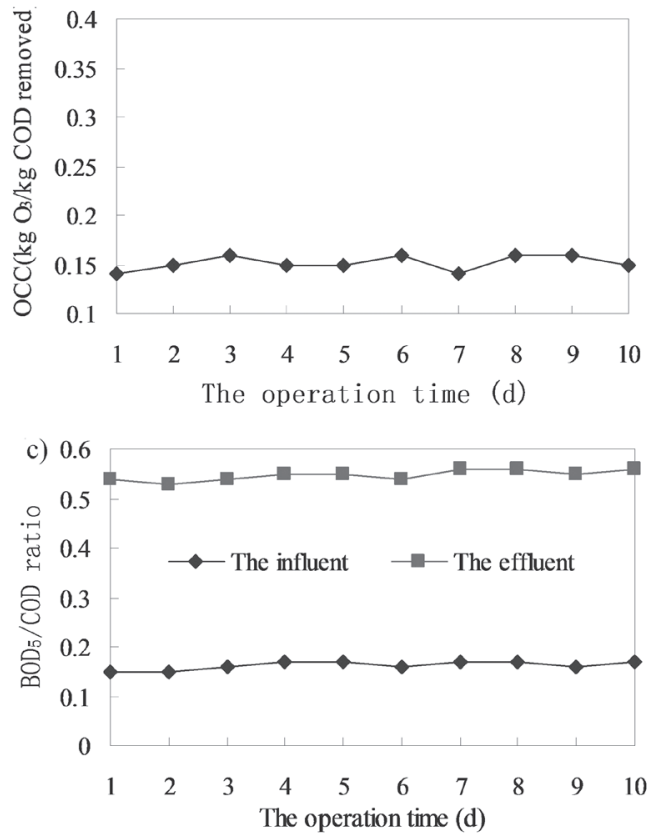

Fig. 5. Effect of ozone/persulfate oxidation: a) pH, b) OCC, c) wastewater biodegradability.

The effect of ozone/persulfate oxidation on wastewater $\mathrm{pH}, \mathrm{OCC}$ and wastewater biodegradability.

\section{Wastewater $\mathrm{pH}$}

Because the subsequent nitrification in UBAF consumes alkalinity, the $\mathrm{pH}$ change of the effluent after ozone/persulfate oxidation was measured (Fig. 5a).

It was obvious that the effluent $\mathrm{pH}$ after oxidation ranged from 7.1 to 8.7 under an initial $\mathrm{pH}$ (7.2-8.9) (Fig. 5a), which means the alkalinity in the effluent could reach the requirement of the subsequent nitrification in UBAF. Furthermore, Fig. 5a) showed the ozone/persulfate oxidation lower $\mathrm{pH}$ values by about $0.1 \mathrm{pH}$ units (average value). This was perhaps because organic acids (e.g., carboxylic acids) were formed during oxidation.

\section{Ozone Consumption Eoefficient (OCC)}

For a continuous operation system, ozone consumption coefficient (OCC) could be calculated as follows:

$$
O C C=\frac{Q_{G} \times C_{A G 0} \times \int_{0}^{t}\left(1-{ }^{C} C_{A G} / C_{A G 0}\right) d t}{V \times\left(C O D_{0}-C O D\right)}
$$

...where $O C C$ was ozone consumption coefficient $(\mathrm{kg}$ $\mathrm{O}_{3} / \mathrm{kgCOD}$ removed), $Q_{\mathrm{G}}$ was the gas flow (L/min), $C_{\mathrm{AG} 0}$ was the concentration of ozone in the input gas $(\mathrm{mg} / \mathrm{L})$, $C_{\mathrm{AG}}$ was the concentration of ozone in the off-gas $(\mathrm{mg} / \mathrm{L})$, $V$ was wastewater volume (L), $t$ was the aerated time in the oxidation stage (min), and $\mathrm{COD}_{0}$ and $\mathrm{COD}$ were respectively $\mathrm{COD}$ concentration in influent and effluent $(\mathrm{mg} / \mathrm{L})$.

As Fig. 5b) illustrated, OCC value during ozone/persulfate oxidation ranged from 0.14 to $0.16 \mathrm{~kg}$ $\mathrm{O}_{3} / \mathrm{kgCOD}$ removed and remained constant at about $0.152 \mathrm{~kg} \mathrm{O} / \mathrm{kgCOD}$ removed on average. A wide variation on OCC value (from less than $1 \mathrm{~kg} \mathrm{O}_{3} / \mathrm{kgCOD}$ removed to up to $16 \mathrm{~kg} \mathrm{O} / \mathrm{kgCOD}$ removed) was reported in the previous studies [30]. The deviation on OCC value maybe due to the differences in wastewater characteristics and experimental conditions (e.g., influent quality, structure of oxidation setup).

\section{Wastewater Biodegradability}

To investigate the effect of ozone/persulfate oxidation on the biodegradability of wastewater (described in terms of $\mathrm{BOD}_{5} / \mathrm{COD}$ ratio), the $\mathrm{BOD}_{5} / \mathrm{COD}$ ratio of the wastewater were determined before and after ozone/ persulfate oxidation. As Fig. 5c) shows, the influent presented poor biodegradability $\left(\mathrm{BOD}_{5} / \mathrm{COD}\right.$ ratio ranged from 0.15 to 0.17 , average value $(0.16)$, but the biodegradability of the effluent after ozone/persulfate oxidation was significantly enhanced $\left(\mathrm{BOD}_{5} / \mathrm{COD}\right.$ ratio ranged from 0.53 to 0.56 , average value 0.55 ). The result indicated that the ozone/persulfate oxidation has good performance on the enhancement of the wastewater biodegradability. The phenomenon was also observed in other studies. Abu Amr et al. [15] reported that the biodegradability of the stabilized leachate after ozone/persulfate oxidation increased from 0.043 to 0.29. Cortez et al. [30] observed an enhancement of biodegradability from 0.01 to 0.17 during $\mathrm{O}_{3} / \mathrm{H}_{2} \mathrm{O}_{2}$ oxidation.

\section{Comparison between Ozone/Persulfate and $\mathrm{O}_{3} / \mathrm{H}_{2} \mathrm{O}_{2}$}

Tang et al. [31] used $\mathrm{O}_{3} / \mathrm{H}_{2} \mathrm{O}_{2}$ oxidation to treat traditional Chinese medicine wastewater, and relevant experiment data are detailed in Table 2.

As Table 2 shows, the ozone/persulfate system obtained a lower operational cost (1.0625 \$/Kg COD removed), and saved $11.4 \%$ on operational costs compared with $\mathrm{O}_{3} / \mathrm{H}_{2} \mathrm{O}_{2}$ oxidation. Furthermore, the ozone/persulfate system achieved a lower OCC value (0.152 $\mathrm{kg} \mathrm{O}_{3} / \mathrm{kgCOD}$ removed), and decreased $24.0 \%$ OCC compared with $\mathrm{O}_{3} / \mathrm{H}_{2} \mathrm{O}_{2}$ oxidation. Finally, the difference on $\mathrm{BOD}_{5} / \mathrm{COD}$ ratio between the two 
Table 2. Comparison between $\mathrm{O}_{3} / \mathrm{S}_{2} \mathrm{O}_{8}{ }^{2-}$ and $\mathrm{O}_{3} / \mathrm{H}_{2} \mathrm{O}_{2}$.

\begin{tabular}{|c|c|c|}
\hline Performance & $\mathrm{O}_{3} / \mathrm{H}_{2} \mathrm{O}_{2}$ & $\mathrm{O}_{3} / \mathrm{S}_{2} \mathrm{O}_{8}{ }^{2}$ \\
\hline $\begin{array}{c}\text { Operational cost } \\
(\$ / \mathrm{kg} \text { COD removed })\end{array}$ & 1.1994 & 1.0625 \\
\hline $\mathrm{BOD}_{5} /$ COD after oxidation & 0.56 & 0.55 \\
\hline OCC & 0.20 & 0.152 \\
\hline
\end{tabular}

Note:

1. The exchange rate on RMB to USD (6.3) was used in this report.

2. Power consumption was $20 \mathrm{kWh} / \mathrm{kgO}_{3}$ during the generating $\mathrm{O}_{3}$.

3. The price on $\mathrm{H}_{2} \mathrm{O}_{2}(27.5 \%)$ was $1000 \mathrm{RMB} / \mathrm{t}$.

4. The price on a power unit was $1.2 \mathrm{RMB} / \mathrm{kWh}$.

5. The price on sodium persulfate $(99 \%)$ was $7000 \mathrm{RMB} / \mathrm{t}$.

6 . The optimum conditions on $\mathrm{O}_{3} / \mathrm{H}_{2} \mathrm{O}_{2}$ were described in the literature [31].

oxidation systems was negligible. These results indicated that compared with $\mathrm{O}_{3} / \mathrm{H}_{2} \mathrm{O}_{2}$ oxidation, the ozone/persulfate system achieved a better enhancement effect in wastewater treatment.

\section{COD Removal Behavior in UBAF}

COD concentrations at various hydraulic loading rates $(L)$ are listed in Table 3.
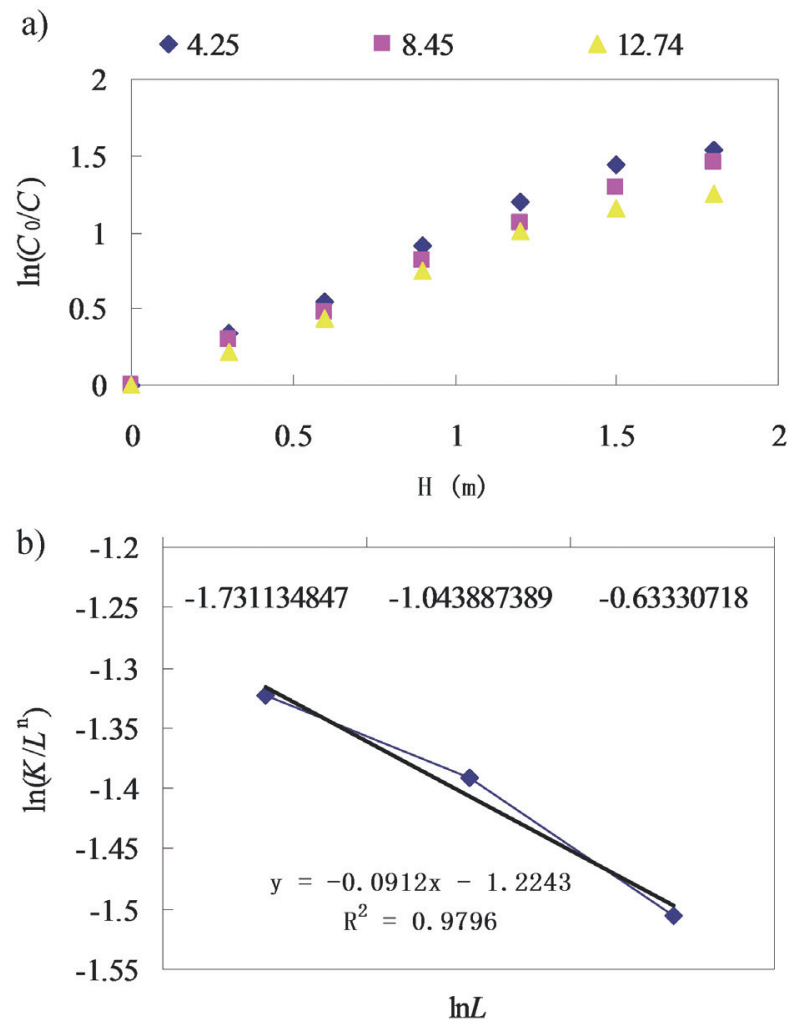

Fig. 6. Relationship between two parameters: a) $\ln \left(C_{0} / C\right)$ with $H$, b) $\ln \left(K / L^{\mathrm{n}}\right)$ with $\ln L$.
Table 3. COD concentrations at various hydraulic loading rates $(L)$.

\begin{tabular}{|c|c|c|c|}
\hline \multirow{2}{*}{$H(\mathrm{~m})$} & \multicolumn{3}{|c|}{ COD value $(\mathrm{mg} / \mathrm{L})$} \\
\cline { 2 - 4 } & $\begin{array}{c}L=4.25 \\
\mathrm{~m}^{3} / \mathrm{m}^{2} \cdot \mathrm{d}\end{array}$ & $\begin{array}{c}L=8.45 \\
\mathrm{~m}^{3} / \mathrm{m}^{2} \cdot \mathrm{d}\end{array}$ & $\begin{array}{c}L=12.74 \\
\mathrm{~m}^{3} / \mathrm{m}^{2} \cdot \mathrm{d}\end{array}$ \\
\hline 0 & 170.0 & 170.0 & 170.0 \\
\hline 0.3 & 120.3 & 126.53 & 136.75 \\
\hline 0.6 & 98.26 & 105.42 & 110.38 \\
\hline 0.9 & 68.24 & 74.86 & 80.67 \\
\hline 1.2 & 51.43 & 58.74 & 62.14 \\
\hline 1.5 & 40.26 & 46.53 & 53.46 \\
\hline 1.8 & 36.45 & 39.52 & 48.56 \\
\hline
\end{tabular}

Table 4. Values of $K / L^{\mathrm{n}}$ and $L$.

\begin{tabular}{|c|c|}
\hline$L\left(\mathrm{~m}^{3} / \mathrm{m}^{2} \cdot \mathrm{d}\right)$ & $K / L^{\mathrm{n}}$ \\
\hline 4.25 & 0.2663 \\
\hline 8.45 & 0.2487 \\
\hline 12.74 & 0.2219 \\
\hline
\end{tabular}

According to Eq. (7), the linear regression of $\mathrm{ln}$ $\left(C_{0} / C\right)$ with $H$ yields the value of at different hydraulic loading rates $(L)$, as shown in Fig. 6a) and Table 4. The linear fitting of with $\ln L$, leads to $\mathrm{n}=0.0912$ and $K=0.2940$, as shown in Fig. 6 b).

Substituting $n$ and $K$ values into Eq. (8) leads to the COD removal kinetics equation as follows:

$$
\frac{C}{C_{0}}=\exp \left(-\frac{0.2940}{L^{0.0912}} H\right)
$$

The COD concentration at different hydraulic loading rates was predicted by Eq. (19) in the UBAF.

\section{Conclusions}

The study investigated performance of the combined ozone/persulfate-UBAF process used to advanced treatment of physically treated effluents from herbal decoction pieces wastewater. Under optimum operational conditions (i.e., initial $\mathrm{pH}$, temperature $\left(13-27^{\circ} \mathrm{C}\right), 30 \mathrm{~min}$ of oxidation, $35 \mathrm{mg} / \mathrm{L} \mathrm{O}_{3}$ dosage, $\mathrm{S}_{2} \mathrm{O}_{8}{ }^{2-} / \mathrm{COD}(\mathrm{g} / \mathrm{g})$ ratio $(0.15)$, gas/liquid ratio in UBAF (3), hydraulic retention time in $\operatorname{UBAF}(5 \mathrm{~h})$ ), the COD and $\mathrm{NH}_{3}-\mathrm{N}$ removal efficiencies were $87.54-89.53 \%$ and $82.94-86.77 \%$ in the combined process respectively, and the ozone/persulfate oxidation achieved an about 55\% COD removal. The results indicated that the combined process could efficiently treat physically treated effluents from herbal decoction pieces wastewater, and that COD 
removal depends on ozone/persulfate oxidation and UBAF, and $\mathrm{NH}_{3}-\mathrm{N}$ removal was mainly attributed to the UBAF. Under optimal conditions, the ozone/persulfate oxidation lowered $\mathrm{pH}$ values by about $0.1 \mathrm{pH}$ units (average value), presented a lower OCC (from 0.14 to $0.16 \mathrm{~kg} \mathrm{O} / \mathrm{kg} \mathrm{COD}$ removed), and significantly improved wastewater biodegradability from 0.16 to 0.55 (average value). Compared with $\mathrm{O}_{3} / \mathrm{H}_{2} \mathrm{O}_{2}$ oxidation, the ozone/persulfate system achieved a better enhancement effect in wastewater treatment (decreased 24.0\% OCC and saved 11.4\% operational costs). This study revealed that the combined process was an efficient technology in treating physically treated effluents from herbal decoction pieces wastewater. Furthermore, under optimum conditions the COD removal rate in the ozone/persulfate oxidation system followed the first order $\ln \left(\frac{C}{C_{0}}\right)=-0.0167 t$, and the COD concentration at different hydraulic loading rates in the BAF was predicted by the model $\frac{C}{C_{0}}=\exp \left(-\frac{0.2940}{L^{0.0912}} H\right)$, which was helpful for applying feasibility improvement of the combined process for other herbal decoction pieces factories.

\section{Acknowledgements}

This work was supported by an open project of the State Key Laboratory of Urban Water Resource and Environment (grant No. QA201525; an open project of Jiangsu Province Key Laboratory of Environmental Material and Environmental Engineering (grant No. K13070); and an open project of Jiangsu Province Key Laboratory of Environmental Engineering (grant No. KF2014009).

\section{Conflict of Interest}

The authors declare no conflict of interest.

\section{References}

1. LV L.Y., LI W.G., YU Y., MENG L.Q., QIN W., WU C.D. Predicting acute toxicity of traditional Chinese medicine wastewater using UV absorption and volatile fatty acids as surrogates. Chemosphere, 194, 211, 2018.

2. LI W.G., LV L.Y., GONG X.J., QIN W., WU C.D, MENG L.Q. Performance evaluation and hydraulic characteristics of an innovative controlled double circle anaerobic reactor for treating traditional Chinese medicine wastewater. Biochemical Engineering Journal, 128,186, 2017.

3. WU C.Y., ZHOU Q.X., SUN X.M., FU L.Y. The recent development of advanced wastewater treatment by ozone and biological aerated filter. Environmental Science and Pollution Research, 25, 8315, 2018.

4. HAN M., ZHAO Z.W., GAO W., CUI F.Y. Study on the factors affecting simultaneous removal of ammonia and manganese by pilot-scale biological aerated filter (BAF) for drinking water pre-treatment. Bioresource Technology, 145, 17, 2013.

5. FU Z.M., ZHANG Y.G., WANG X.J. Textiles wastewater treatment using anoxic filter bed and biological wriggle bed-ozone biological aerated filter. Bioresource Technology, 102, 3748, 2011.

6. BASHIR M.J.K., AZIZ H.A., YUSOFF M.S. New sequential treatment for mature landfill leachate by cationic/anionic and anionic/cationic processes: optimization and comparative study. Journal of Hazardous Materials, 186, 92, 2011.

7. GHAUCH A., TUQAN A., KIBBI N. Ibuprofen removal by heated persulfate in aqueous solution: a kinetics study. Chemical Engineering Journal, 197, 483, 2012.

8. GHAUCH A., TUQAN A., KIBBI N. Methylene blue discoloration by heated persulfate in aqueous solution. Chemical Engineering Journal, 213, 259, 2012.

9. FURMAN O.S., TEEL A.L., WATTS R.I. Mechanism of base activation of persulfate. Environmental Science \& Technology, 44, 6423, 2010.

10. OLMEZ-HANCI T., ARSLAN-ALATON I., GENC B. Bisphenol A treatment by the hot persulfate process: oxidation products and acute toxicity. Journal of Hazardous Materials, 263, 283, 2013.

11. LI T.T., FANG Z., YU R., CAO X., SONG H.L., LI X.N. The performance of the microbial fuel cell-coupled constructed wetland system and the influence of the anode bacterial community. Environmental Technology, 37, 1683, 2016.

12. LI TT, FANG Z., YU R., CAO X., SONG H.L., LI X.N. Degradation of MDEA in aqueous solution in the thermally activated persulfate system. Environ Technology, 38, 730, 2017.

13. LOMINCHAR M.A., SERGIO R., DAVID L., NOELIA S., ARTURO R., AURORA S. Phenol abatement using persulfate activated by nZVI, $\mathrm{H}_{2} \mathrm{O}_{2}$ and $\mathrm{NaOH}$ and development of a kinetic model for alkaline activation. Environ Technology, 38, 35, 2018.

14. GUNTEN U.V. Ozonation of drinking water: Part I. Oxidation kinetics and product formation. Water Research, 37, 1443, 2003.

15. ABU AMR S.S., ABDUL AZIZ H., MOHD NORDIN A., BASHIR M.J.K. Pretreatment of stabilized leachate using ozone/persulfate oxidation Process. Chemical Enginering Journal, 221, 492, 2013.

16. Environment Protection Bureau of China. Analytical Methods of Water and Wastewater, fourth ed.; China Environment Science Press: Beijing, China, 2012 [In Chinese].

17. SHEN J.Y., HE R., WANG L.J., HAN W.Q., LI J.S., SUN X.Y. Kinetics of COD removal in a biological aerated filter in the presence of 2,4,6-Trinitrophenol (Picric Acid). Chinese Journal of Chemical Engineering journal, 17, 1021, 2009.

18. HILLES A.H., ABU AMR S.S., HUSSEIN R., EL-SEBAIE O.D., ARAFA A.I. Performance of combined sodium persulfate/ $\mathrm{H}_{2} \mathrm{O}_{2}$ based advanced oxidation process in stabilized landfill leachate treatment. Journal of Environmental Management, 166, 493, 2016.

19. LU Y.S., YANG X.X., XU L., WANG Z., XU Y.F., QIAN G.R. Sulfate radicals from $\mathrm{Fe}^{3+} /$ persulfate system for Rhodamine B degradation. Desalination and Water Treatment, 57, $29411,2016$.

20. PENNINGTON D.E., HaimA. Stoichiometry and mechanism of the chromium (II) peroxydisulfate reaction. 
Journal of The American Chemical Society, 90, 3700, 1968.

21. HAYON E., TREININ A., WILF F. Electronic spectra, photochemistry, and autoxidation mechanism of the sulfite-bisulfite-pyrosulfite systems. The $\mathrm{SO}_{2}^{-}, \mathrm{SO}_{3}^{-}, \mathrm{SO}_{4}^{-}$ and $\mathrm{SO}_{5}^{-}$Radicals. Journal of The American Chemical Society, 91, 47, 1972.

22. TOMIYASU H., FUKUTOMI H., GORDON G. Kinetics and Mechanism of Ozone Decomposition in Basic Aqueous Solution. Inorganic Chemistry, 24, 2962, 1985.

23. YANG Y., GUO H.G., ZHANG Y.L., DENG Q.Z., ZHANG J. Degradation of Bisphenol a using ozone/ persulfate process: kinetics and mechanism. Water Air Soil Pollution, 227, 52, 2016.

24. QI L., WANG X.J., XU Q.K. Coupling of biological methods with membrane filtration using ozone as pretreatment for water reuse. Desalination, 270, 264, 2011.

25. SHABIIMAM M.A., DIKSHIT A.K. Treatment of municipal landfill leachate by oxidants. American Journal Environment Engineering, 2, 1, 2012.

26. ZHENG L., WANG X.J., WANG X.Z. The treatment of reverse osmosis concentrate from textile and dying industry with persulfate oxidation and lime-soda softening. Acta Scientiae Circumstantiae, 36, 166, 2016 [In Chinese].
27. KONDRAKOV A.Q., IGNATEV A.N., FRIMMEL F.H., BRASE S., HOM H., REVELSKY A.I. Formation of genotoxic quinones during bisphenol A degradation by $\mathrm{TiO}_{2}$ photo catalysis and UV photolysis: a comparative study. Applied Catalysis B: Environmental, 160,106, 2014.

28. GAO Y.Q., GAO N.Y., DENG Y., YANG Y.Q., MA Y. Ultraviolet (UV) light-activated persulfate oxidation of sulfamethazine in water. Chemical Engineering Journal, 195, 248, 2012.

29. GUO C., GE M., LIU L., GAO G., FENG Y., WANG Y. Directed synthesis of mesonporous $\mathrm{TiO}_{2}$ microspheres: catalysts and their photocatalysts for bisphenol A degradation. Environmental Science \& Technology, 44, 419, 2010.

30. CORTEZ S., TEIXEIRA P., OLIVEIRA R., MOTA M. Ozonation as polishing treatment of mature landfill leachate. Journal of Hazardous Materials, 182, 730, 2010.

31. TANG G.M., JIA Z.H., YU X.M., LIN D.X., WANG H., MA F., XU W., ZHAN C.J., WANG Y. New advanced treatment of biologically treated effluents from traditional Chinese medicine wastewater using the coupling process of $\mathrm{O}_{3} / \mathrm{H}_{2} \mathrm{O}_{2}$-BAF. Journal of the Taiwan Institute of Chemical Engineers, 56, 167, 2015. 